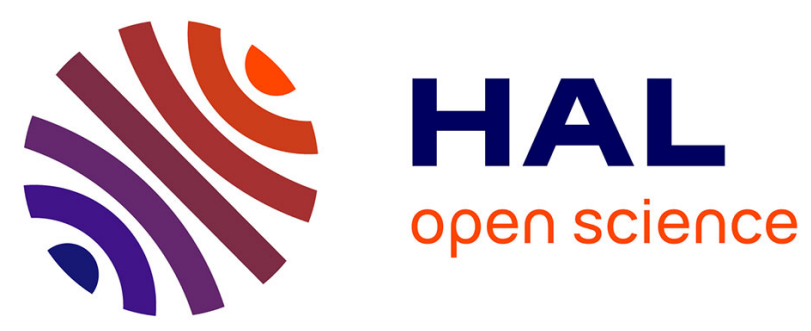

\title{
Preventive services recommendations for adults in primary care settings: agreement between Canada, France and the USA-a systematic review.
}

\author{
Julien Gelly, France Mentré, Michel Nougairede, Xavier Duval
}

\section{To cite this version:}

Julien Gelly, France Mentré, Michel Nougairede, Xavier Duval. Preventive services recommendations for adults in primary care settings: agreement between Canada, France and the USA-a systematic review.. Preventive Medicine, 2013, 57 (1), pp.3-11. 10.1016/j.ypmed.2013.03.012 . inserm-00812066

\section{HAL Id: inserm-00812066 https://www.hal.inserm.fr/inserm-00812066}

Submitted on 11 Apr 2013

HAL is a multi-disciplinary open access archive for the deposit and dissemination of scientific research documents, whether they are published or not. The documents may come from teaching and research institutions in France or abroad, or from public or private research centers.
L'archive ouverte pluridisciplinaire HAL, est destinée au dépôt et à la diffusion de documents scientifiques de niveau recherche, publiés ou non, émanant des établissements d'enseignement et de recherche français ou étrangers, des laboratoires publics ou privés. 


\section{Preventive services recommendations for adults in primary care settings:}

\section{Agreement between Canada, France and the USA - A systematic review}

AUTHORS: Julien GELLY ${ }^{\mathrm{a}, \mathrm{b}, \mathrm{c}}$, France MENTRE ${ }^{\mathrm{b}, \mathrm{c}}$, Michel NOUGAIREDE $^{\mathrm{a}}$, Xavier DUVAL ${ }^{\mathrm{b}, \mathrm{c}, \mathrm{d}}$
a. Univ Paris Diderot, Sorbonne Paris Cité, Dept of General Practice, F-75018 Paris, France
b. Univ Paris Diderot, Sorbonne Paris Cité, UMR 738, F-75018 Paris, France
c. INSERM, UMR 738, F-75018 Paris, France
d. APHP, INSERM, CIC 007, Hôpital Bichat, Paris, France

CORRESPONDING AUTHOR: Julien GELLY

Département de médecine générale

Université Paris Diderot - Paris 7, Site Bichat

16 rue Henri Huchard

75018 Paris, France

Tel: 0033682110768 / e-mail adress: julien.gelly@univ-paris-diderot.fr

WORD COUNT: Main text $=4071(\mathrm{~N} \leq 4500) \quad / \quad$ Abstract $=200(\mathrm{~N} \leq 200)$

\section{ABBREVIATIONS:}

ANAES: the previous acronym for the French National Authority for Health (until 2004); AFSSAPS: French Agency for the Safety of Health Products; CTFPHC: Canadian Task Force on Preventive Health Care; HAS: the current acronym for the French National Authority for Health; INCa: French National Cancer Institute; NICE: National Institute for Health and Clinical Excellence; RACGP: Royal Australian College of General Practitioners; USPSTF: United States Preventive Services Task Force. 


\section{ABSTRACT}

OBJECTIVE: To analyze the level of agreement between recommendations on preventive services developed by Canada, France and the USA.

METHODS: We gathered recommendations on primary and secondary preventive services to adults up to November $3^{\text {rd }}, 2011$ from Canadian and US Task Forces, and equivalent French agencies. We excluded recommendations on immunization, long-term diseases or pregnancy.

RESULTS: Among 250 recommendations, 84 (34\%) issued by a single country could not be compared; 43 (26\%) of the remaining 166 were in strong agreement (strictly identical grades between advising countries); 25 of 43 resulted in a proposal to be implemented in clinical practice, two others not to be implemented in clinical practice and 16 were indeterminate about implementation. Strong agreement was more frequent for recommendations concerning history-taking and physical examination than for those concerning interventions (odds ratio $(\mathrm{OR})=11.3,95 \% \mathrm{CI}$ : $1.6-241.2 ; p=$ 0.04), and for recommendations concerning a high-risk population than for those concerning the general population ( $\mathrm{OR}=3.1,95 \% \mathrm{CI}: 1.4-7.0 ; p=0.006)$. Agreement did not differ either according to maximum time range between recommendations' publication or according to the advising country.

CONCLUSION: Agreement between recommendations is low particularly on those concerning nonclinical preventive services or non-high-risk individuals.

KEYWORDS: Preventive Health Services ; Primary Health Care ; Guidelines as Topic ; EvidenceBased Medicine ; Recommendations ; Agreement between countries. 


\section{INTRODUCTION}

Many leading causes of death and disability - including those due to certain types of cancer, cardiovascular diseases, infectious diseases or diabetes - are associated with identified risk factors, opening the way to preventive strategy policies (World Health Organization, 2011). Health promotion and disease prevention have become integral components of primary health care (Allen et al., 2011), and general practitioners (GP) hold a strategic position in delivering preventive services (Hulscher et al., 2006). During the last thirty years, several countries have developed evidence-based recommendations for periodic health examinations, such as the Canadian Task Force on Preventive Health Care (CTFPHC, since 1979) (Canadian Task Force on Preventive Health Care [CTFPHC], 2012; Public Health Agency of Canada 1994) and the United States Preventive Services Task Force (USPSTF, since 1983) (U.S. Preventive Services Task Force [USPSTF], 2010a), which often worked in close cooperation. Many other national agencies have focused their guidelines on diseases and their curative treatment, among which specific recommendations on preventive care are scattered (French National Authority for Health, 2009). For each recommendation, the grading system used to recommend or not a particular action depends on the quality of available evidence concerning a preventive service for a given target population, assessing its benefits and harms to health outcomes.

Implementation of evidence-based guidelines in clinical practice is a critical issue, whether for preventive or curative strategies (Harris et al., 2011; Hulscher et al., 2006). Actual rates of preventive service delivery remain low: around 50\% for screening, $25 \%$ for immunization, and less than $10 \%$ for counseling services (Krist et al. 2012; Stange et al., 2000; Yarnall et al., 2003). Many elements absence of a reminder system, reimbursement, time, awareness or outcome expectancy - contribute to adherence barriers (Cabana et al., 1999; Carlsen and Bringedal, 2011; Lugtenberg et al., 2011; Yarnall et al., 2003). In addition, the failure to reach consensus within the whole body of existing recommendations is a major concern (Burgers et al., 2003; Grol, 2001; Hutchings and Raine, 2006; McMurray and Swedberg, 2006). Beyond the overcoming organizational barriers, a better consensus between national agencies could improve adherence to clinical practice guidelines in primary care settings.

In International literature, very few comparisons between the findings of national agencies can be found. Most of them targeted a specific field or a specific population (Burgers et al, 2002; Kanis et al., 2000; Mallery et al., 1992; McMurray and Swedberg., 2006). Some international agencies have analyzed recommendations on specific preventive topics published across countries (International Agency for Research on Cancer, 2013; National Cancer Institute, 2012). To date, comparisons between Canada and the USA are rare or old (Mavriplis and Thériault, 2006; Milone and Milone, 
2006; Hayward et al., 1991; Agency for Healthcare Research and Quality, 2013), and there have been no comparisons between recommendations on preventive care issued by other countries. Above all, no methodology has been developed to perform a comprehensive comparison of all preventive services in adults, allowing to quantify the level of agreement between several countries and to assess its determinants.

In this context, it seemed important to describe the recommendations from three various countries, to analyze their level of agreement, to compile a list of the most consensual recommendations and to assess the determinants of strong agreement.

\section{METHODS}

\section{RECOMMENDATIONS - SOURCES AND SEARCH FOR}

We chose Canada and the United States of America (USA) because their recommendations on preventive care have long been world-notorious. For the Canadian recommendations, we included those from the new CTFPHC website (CTFPHC, 2012) or, if lacking, the latest version of the Canadian Guide to Clinical Preventive Health Care published (Public Health Agency of Canada, 1994). For the US recommendations, we used those from the USPSTF's Guide to Clinical Preventive Services (USPSTF, 2010a).

We added France as a European country publishing recommendations focused on curative treatment. Because there was no single French agency publishing preventive services guidelines, we included all relevant recommendations published by the French National Authority for Health (called HAS in French, and ANAES until 2004) (French National Authority for Health, 2011). If none were found, we completed our research by querying the catalogue and index of French-language medical sites, which is a quality controlled health information portal using a terminology based on the Medical Subject Headings thesaurus (Sakji et al., 2009).

\section{RECOMMENDATIONS - SELECTION}

We retrieved recommendations on preventive care in Canada, France, and the USA. We consulted websites and databases for the last time on November $3^{\text {rd }}, 2011$. We considered that any of those which were accessible on the official websites were still relevant. We included all recommendations found regarding primary and secondary prevention in asymptomatic adults (Leavell and Clark, 1965), 
except those dedicated to very specific populations (pregnant women or people already suffering from long-term disease or injury, considered as tertiary prevention) or published by specific national agencies (immunization) [Appendix Method 1].

\section{RECOMMENDATIONS - EXTRACTION AND SPLITTING}

Given the discrepancies among the countries between the scope of a recommendation and the target population, we decided to split the recommendations to allow one-to-one comparisons between countries. We performed this splitting as needed on three successive levels: "topics of recommendation" (e.g. breast cancer, colorectal cancer, coronary heart disease, tobacco use); "preventive services" (e.g. screening for breast cancer by self-examination, by mammography, or by magnetic resonance imaging); target population as defined by gender, age and risk level for disease occurrence) [Appendix Figure 1]. The splitting did not take into account the recommended frequency of each preventive service. We defined the final products of splitting as a "targeted recommendation" [Appendix Method 2].

\section{RECOMMENDATIONS - SYNTHESIS AND GRADING}

The grading system of a recommendation depended on the quality of evidence assessing the benefit/risk balance of a preventive service for a given target population. Each country adopted its own grading system to strongly or weakly recommend or discourage implementing preventive services for a given target population (CTFPHC, 2003; French National Authority for Health, 2010; Public Health Agency of Canada, 1994; UUSPSTF, 2008a). In some cases, the French grading system also takes into account practices and expert opinions, referred to as a "Professional Consensus" [Appendix Table 1]. To allow a comparison between countries for a targeted recommendation, we determined equivalences between these different grading systems [Table 1]. Thus, we defined an "equivalent grade of recommendation" for each targeted recommendation.

For any targeted recommendation allowing comparison between at least two countries, we defined strong agreement as when the related equivalent grades of recommendation were strictly identical among the three advising countries, or between two of them when only two countries advised a particular targeted recommendation. We defined as major disagreement when at least one country recommended a preventive service whereas another did not (or vice versa), or if the gap between equivalent grades of recommendation was greater than or equal to two. We defined all other cases allowing comparison as intermediate agreement. 
We categorized recommendations in six clinical categories: cancers; cardiovascular diseases; infectious diseases; injury and mental health and musculoskeletal disorders; metabolic and nutritional and endocrine conditions; and miscellaneous. Recommendations were also classified in four categories according to the sequence of steps of the medical consultation addressed in the recommendation: patient history-taking and physical examination, counseling, techniques and procedures, or intervention. We defined the target population in terms of gender (only for men, only for women, or for both genders), age (individuals over 50, individuals under 50, or different age limits) and the risk level for disease occurrence (general population or high-risk population, i.e. any individual whose risk was higher than the general population). We computed the "maximum time range between recommendations' publication" as the number of years between the latest and oldest recommendation publications. We discretized it by 5 years. Finally, we assigned for each targeted recommendation a "proposal for clinical practice" among three modalities resulting from the average of the three countries' equivalent grades of recommendation: "To be implemented" if $[+1 ;+2]$, "Indeterminate about implementation" if ]-1;+1[ and "Not to be implemented" if [-2;-1].

\section{STATISTICAL ANALYSES}

Our objectives were 1) to describe the level of agreement between the recommendations on preventive services published by Canada, France and the USA; 2) to list the most consensual recommendations, consisting of the targeted recommendations with strong agreement and a definite proposal for clinical practice (except those indeterminate about implementation); 3) to assess the determinants of strong agreement.

We described the characteristics of country-specific targeted recommendations according to their clinical category, the sequence of steps of the medical consultation, the target population, and the grading information. In order to assess the level of agreement, we focused only on the final products of splitting so called "targeted recommendation" and not on the first two levels of splitting. We compiled a list of the targeted recommendations with strong agreement between countries and a definite proposal for clinical practice (To be implemented, or Not to be implemented).

We analyzed the determinants of strong agreement (vs. intermediate agreement or major disagreement) for all the targeted recommendations that allowed at least a two-country comparison. First, using Fisher's exact test, we assessed the link between strong agreement and the following variables: clinical category, sequence of steps of the medical consultation, target population (gender, age and risk level for disease occurrence), and maximum time range between recommendations' publication. Second, we included the same variables in a logistic regression model. After a first screening by univariate analysis, the multivariate analysis started with a model that included all 
variables with a $\mathrm{p}$ value $\leq 0.20$ according to the univariate analysis. A backward selection was then performed to retain only the significant variables in the model.

We performed all data analyses using R-software, version 2.12.1 (R Foundation, from http://www.r-project.org, Auckland, New Zealand). This study had no external funding source.

\section{RESULTS}

\section{RECOMMENDATIONS - SELECTION AND FIRST LEVEL OF SPLITTING}

Our search yielded 77 topics of recommendation published by any of the three countries. Their distribution according to clinical categories was homogeneous across countries [Appendix Table 2]. Canada and France's recommendations first targeted Cancers and Infectious diseases, while Cancers came only as fourth main clinical category in terms of number of topics in US recommendations. Among the 77, four topics of recommendation met one of the predefined non-inclusion criteria. In addition, six of the remaining 73 topics of recommendation (8\%) did not make any comparison between countries possible [Figure 1].

\section{FURTHER SPLITTING TO REACH TARGETED RECOMMENDATIONS}

At the second level of splitting, our chart yielded 136 distinct preventive services. Among them, fifty met at least one of our predefined non-inclusion criteria. Three of the 86 remaining topics of recommendations (3\%) did not make any comparison between countries possible [Figure 1].

At the third level of splitting, our chart yielded 250 distinct targeted recommendations. Among them, 84 out of 250 (34\%) targeted recommendations did not allow any comparison between countries. The remaining $166(66 \%)$ targeted recommendations allowed either a two-country (111 $(44 \%)$ ) or a three-country (55 (22\%)) comparison and were matched one-to-one for a given target population (gender, age and/or risk level for disease occurrence) [Figure 1].

\section{CHARACTERISTICS OF 250 COUNTRY-SPECIFIC TARGETED RECOMMENDATIONS}

The 250 targeted recommendations were homogeneously distributed according to clinical categories across countries [Table 2]. At this level of splitting, we found the targeted recommendations were primarily related to cancers (32 to $41 \%$ ) or cardiovascular diseases (14 to $22 \%$ ). Concerning their 
place in the sequence of steps of the medical consultation, targeted recommendations related to counseling were more frequent in Canada (32\%) than France $(26 \%)$ or the USA $(17 \%)$. The distribution related to technical procedures followed the reverse order (US: 62\%; France: 52\%; Canada: $17 \%)$.

The proportions of targeted recommendations according to target population were very similar whether for gender, age or risk level for disease occurrence [Table 2]. Most of them related to both genders (40 to 58\%). They were not specific to individuals either over or under 50 (60 to 63\%). They mostly concerned the general population (Canada: 75\%; France: 67\%; USA; 75\%).

Looking at the equivalent grade of recommendation, the French targeted recommendations were rarely (3\%) graded " 0 " (i.e. no recommendation or insufficient evidence) compared to the ones in Canada and the USA (45\%, and $34 \%$ respectively). In contrast, grades of " +1 " and " -1 " were more frequent in French recommendations (France: 64\% and 24\%, vs. Canada: 29\% and 15\%, USA: 16\% and $6 \%$ respectively). Negative grades of "-2", recommending with good evidence the exclusion of a preventive service, were very rare in Canada and France (1\% and 2\%, respectively) but represented $30 \%$ of US targeted recommendations [Table 2].

\section{LEVEL OF AGREEMENT AND LIST OF THE MOST CONSENSUAL TARGETED RECOMMENDATIONS}

Among the 166 out of $250(66 \%)$ targeted recommendations where comparison was possible between at least two countries, $43(26 \%)$ were in strong agreement, $82(49 \%)$ in intermediate agreement and $41(25 \%)$ in major disagreement [Table 3].

Two out of 43 (5\%) targeted recommendations with Strong agreement resulted in a Not to be implemented proposal for clinical practice: screening of asymptomatic bacteriuria in high-risk populations over 65 years (equivalent grade “-2”), and screening of Chlamydia infection in the general population over 25 years (equivalent grade “-1”) [Table 4].

Twenty-five out of $43(58 \%)$ targeted recommendations with strong agreement resulted in a To be implemented proposal for clinical practice: 11 of these concerned the general population, and the remaining 14 a high-risk population. Among the 11 targeted recommendations concerning the general population, there was only one "strongly recommend", counseling smoking cessation for smokers (equivalent grade "+2"). All other equivalent grades for the remaining 10 targeted recommendations were " +1 ": referring smokers to validated program, alcohol misuse (screening and counseling), rubella (screening, for women of childbearing age), osteoporosis (history of previous fractures), depression (screening, under condition), and general dietary advice on fat and cholesterol in 30-69 year old men to prevent coronary heart disease [Table 4]. 
Among the 14 targeted recommendations concerning a high risk population, all had an equivalent grade of " +1 ": breast and ovarian cancer (referral for genetic counseling depending on family history), colorectal cancer (genetic testing and screening for kindred with cancer family syndrome), cardiovascular disease (counseling healthy diet, screening for lipid disorders or type 2 diabetes), osteoporosis (screening using Body Mineral Densitometry in high-risk women), and sexually transmitted infections (counseling for individuals identified at high-risk of such infections).

The remaining 16 out of 43 (37\%) targeted recommendations with strong agreement resulted in an Indeterminate about implementation proposal for clinical practice.

\section{DETERMINANTS OF STRONG AGREEMENT BETWEEN COUNTRIES ON TARGETED RECOMMENDATIONS}

Strong agreement among countries was not related to the clinical category of the recommendation, the age of the target population, or the maximum time range between recommendations' publication. Strong agreement was more frequent when targeted recommendations concerned history-taking or physical examination $(53 \%)$ rather than intervention $(8 \% ; p=0.01)$. Strong agreement was more common for targeted recommendations related to both genders $(p=0.04)$ or high-risk populations $(p=0.009)$. In addition, strong agreement rates did not differ significantly when comparisons of recommendations were restricted to a pair of countries (France-US comparison: $16 \%$ in strong agreement; Canada-France comparison: $21 \%$ in strong agreement; Canada-US comparison: $27 \%$ in strong agreement) [Appendix Table 3].

In the multivariate analysis [Appendix Table 4], the proportion with strong agreement between countries was higher for recommendations based on history-taking and physical examination than on those based on intervention (odds ratio $(\mathrm{OR})=11.3,95 \% \mathrm{CI}=[1.6-241.2] ; p=0.04$ ), and for recommendations concerning high-risk populations $(\mathrm{OR}=3.1,95 \% \mathrm{CI}=[1.4-7.0] ; p=0.006)$ as compared to the general population.

\section{DISCUSSION}

In our study, which aimed at comparing the scope and agreement between recommendations on preventive services for adults in general practice originating from three industrialized countries (Canada, France and the USA), the recommendations showed a low level of agreement. The proportion of strong agreement among the targeted recommendations (26\%) decreased according to its 
place in the sequence of steps of the medical consultation (from history-taking and physical examination, to intervention: $53 \%$ down to $8 \%$ ). This level of agreement was higher for recommendations concerning specific populations identified as high-risk, than for those concerning the general population ( $41 \%$ vs. $20 \%$ ). Furthermore, this study highlights some "consensual" preventive services which the clinician should pay special attention to [Table 4].

Despite the clear interest of all three countries in preventive care as evidenced by the large number of recommendations, the recommendation methodology, grading system, means of expression, clinical categories, as well as the populations targeted, were all highly variable, which complicated any comparison of the preventive services recommended by each country (Hayward et al., 1991). The divergence in topics addressed by the three different countries, which made it impossible to compare around ten percent of the global recommendations, could be explained in several ways: a difference in the perception of certain preventive services as essential priorities; differences in the epidemiology of certain illnesses; or differences in health delivery systems and medical coverage (Organisation for Economic Co-operation and Development, 2011; Starfield, Shi and Macinko, 2005; USPSTF, 2010b; USPSTF, 2010c). This impossibility of comparing recommendations existed despite our deliberate choice of three countries with well-developed health care systems whose means allow them the luxury of focusing on prevention rather than exclusively on priorities that are more basic. Surprisingly, some of the recommendations that could not be compared related to prevailing issues: chronic obstructive pulmonary disease, high blood pressure, illicit drug use, peripheral arterial disease, and unintended pregnancy [Figure 1]. This cannot be due to variations in access to scientific information, as these recommendations were founded on the analysis of evidence-based medical data that are available to the experts in all three countries (McAlister et al., 2007). The discrepancies between recommendations on preventive care could also be explained by political willingness, or socioeconomic and cultural contexts (Atkins et al., 2004). Considering the lack of consideration on patient characteristics too, this may affect the applicability and the transferability of recommendations in clinical practice (Ahmad et al., 2010; Herland et al., 2005).

Not surprisingly, these disparities in the choice of topics of recommendations were accentuated when considering more specific services relative to a precise target population (our third level of splitting), leading to an absence of comparisons between countries for 84 out of 250 (34\%) targeted recommendations. In order to avoid over-accentuating the major disagreement factor when comparing the 166 comparable targeted recommendations, we deliberately considered that the absence of a given recommendation in one country did not downgrade agreement on the same recommendation existing in the other two. Failure to apply this consideration would have resulted in strong agreement on only $9 / 166(5 \%)$ and in major disagreement on 125/166 (75\%) of all the included targeted recommendations, an even lower rate than our $26 \%$ of strong agreement. It is noteworthy that the lack of a recommendation issued by a given country was more often the case with France than with the 
USA or Canada, which could be due to the absence of any health structure specifically dedicated to prevention within the French health system. The scope of country-specific targeted recommendations seemed consistent in reference to the sequence of steps of the medical consultation and target population. Most of them related to a nonspecific population in terms of gender, age and risk level for disease occurrence.

Inter-country differences concerned not only topics but also grading systems. Recommendations categorized as having "good evidence to be recommended" rarely appeared among the recommendations inciting strong agreement. This is probably due to the scarcity of strong scientific evidence in support of the public health interest of preventive services. Moreover, the USA was more inclined to discourage strategies (30\% of the recommendations). This important finding may reflect a marked focus on cost benefit analysis in USPSTF, and in the US guidelines (USPSTF, 2008b).

In order to better explain the discrepancies, we looked for the determinants of strong agreement. Contrary to expectations, it was neither the country, nor the type of pathology, nor the maximum time range between two recommendations or their relevance to frequent pathologies which governed their agreement. Above all, the age of the Canadian Guide to Clinical Preventive Health Care (which is still available on line for clinicians), and the disbanding of the CTFPHC between 2006 and 2011 (CTFPHC, 2012; Public Health Agency of Canada, 1994) don't significantly influence the level of agreement between countries. Our considering the recommendations issued by France and the USA did not increase the level of agreement [Appendix Table 3]. The determinants of strong agreement between countries were only the identification of a high-risk population, as well as historytaking and physical examination. We can wonder whether the discrepancies between guidelines could be due more to differences in health care systems than to differences in scientific interpretation (McAlister et al., 2007). The currently available data do not allow us to differentiate recommendations based on purely scientific knowledge from those taking into account the feasibility of their application within existing health care systems.

We must acknowledge several limitations to our study. First, for feasibility concerns, we did not retain other well-known recommendations such as those from the Royal Australian College of General Practitioners (RACGP) (Royal Australian College of General Practitioners, 2009) or the National Institute for Health and Clinical Excellence's (NICE). RACGP's grading system differs from those used by the three countries in our study, and would need a more sophisticated process to overcome the problem of equivalencies. NICE guidance programs make recommendations that could improve health or prevent disease. Nevertheless, they use no specific grading system to assess each recommendation (National Institute for Health and Clinical Excellence, 2012). Our collection of recommendations was thus not exhaustive, but a more exhaustive approach would have tended to 
reduce rather than increase the level of agreement between countries. Second, to allow comparisons between countries, we were obliged to consider equivalencies in different grading systems. We have deliberately chosen to attribute an equivalent grade of "+1" or " -1 " for the French "Professional consensus" which takes into account practices and expert opinions when evidence is insufficient, because it is often a default grade for French recommendations. However, we performed a sensitivity analysis considering "Professional consensus" as an equivalent grade of "0". We found quite a similar proportion of strong agreement $(46 / 166 ; 28 \%)$, intermediate agreement $(79 / 166 ; 48 \%)$ and major disagreement $(41 / 166 ; 25 \%)$.. Third, none of our selection criteria concerned the time of publication. We could have chosen to retain only the most recent recommendations. A period of research over the last 5 years would have been appropriate, given the frequency of renewal encouraged by the agencies (CTFPHC, 2011; French National Authority for Health, 2010; USPSTF, 2008b). Such an analysis would have led to a decrease in the number of included recommendations and to restricting their scope. Considering only the 24/166 (14\%) recommendations updated during the last 5 years, their level of agreement was not much better: 9 strong agreement (38\%), 12 intermediate agreement (50\%) and 3 major disagreement (12\%) [Data not shown]. It is in agreement with our findings that the average time interval between the date of the study and each recommendations 'publication did not influence significantly the level of agreement between recommendations (Fisher's exact test: $p=0.16$ ) [Data not shown]..

\section{CONCLUSIONS}

In conclusion, to the best of our knowledge, this study highlights for the first time the low level of agreement between national recommendations related to primary and secondary preventive services for asymptomatic adults in three countries. Neither the time of their publication, nor the methodology used by the agencies, seem to greatly influence the level of agreement between the three countries. The level of agreement was even greater if the recommendations related to a step of the medical consultation seen as minimally invasive and cost-effective (history-taking and physical examination) or for individuals already identified at high-risk. These findings suggest what should be subject to special attention in primary care settings, which may be particularly useful to guideline producers or consumers. Another noteworthy implication of this study is for adopting best practices for guidelines producers. Developing trustworthy guidelines with a strong level of agreement would imply a harmonization of methodologies (Brouwers et al., 2010; Qaseem et al., 2012) and greater international collaboration could enhance the updating process. It might be of interest to produce twolevel guidelines: the first one should only be based on evidence and trustworthy whatever the country; the second one should take into account local specificities (in terms of epidemiology, health care 
system, availability of technologies, or practice patterns). This could improve practical implementation in many countries, and adherence to comprehensive preventive services guidelines in primary care settings (Starfield, Shi and Macinko,2005). 


\section{CONFLICTS OF INTEREST STATEMENT}

The authors declare that there are no conflicts of interest. 


\section{ACKNOWLEDGEMENTS}

Françoise Lycakis, for proof reading the manuscript, and Dr Thomas Cartier for writing assistance. 


\section{REFERENCES}

Agency for Healthcare Research and Quality, 2013. National Guideline Clearinghouse, viewed 22 February 2013, http://appliedresearch.cancer.gov/icsn/http://www.guideline.gov/compare/compare.aspx

Ahmad, N., Boutron, I., Dechartres, A., Durieux, P., Ravaud, P., 2010. Applicability and generalisability of the results of systematic reviews to public health practice and policy: a systematic review. Trials 11, 20.

Allen, J., Gay, B., Crebolder, H., Heyrman, J., Svab, I., Ram, P., 2011. The European definition of General Practice / Family Medicine (second edition), WONCA Europe, viewed 12 November 2012 , http://www.woncaeurope.org/sites/default/files/documents/Definition\%203rd\%20ed\%202011 $\% 20$ with\%20revised\%20wonca\%20tree.pdf

Atkins, D., Best, D., Briss, P.A., Eccles, M., Falck-Ytter, Y., Flottorp, S., Guyatt, G.H., Harbour, R.T., Haugh, M.C., Henry, D., Hill, S., Jaeschke, R., Leng, G., Liberati, A., Magrini, N., Mason, J., Middleton, P., Mrukowicz, J., O'Connell, D., Oxman, A.D., Phillips, B., Schünemann, H.J., Edejer, T.T., Varonen, H., Vist, G.E., Williams, J.W. Jr., Zaza, S., GRADE Working Group, 2004. Grading quality of evidence and strength of recommendations. BMJ 328, 1490.

Brouwers, M.C., Kho, M.E., Browman, G.P., Burgers, J.S., Cluzeau, F., Feder, G., Fervers, B., Graham, I.D., Grimshaw, J., Hanna, S.E., Littlejohns, P., Makarski, J., Zitzelsberger, L, AGREE Next Stepts Conortium, 2010. AGREE II: advancing guideline development, reporting, and evaluation in health care. Prev. Med. 51, 421-424.

Burgers J.S., Bailey J.V., Klazinga N.S., Van Der Bij A.K., Grol R., Feder G., AGREE collaboration, 2002. Inside guidelines: comparative analysis of recommendations and evidence in diabetes guidelines from 13 countries. Diabetes Care 25, 1933-1939.

Burgers, J.S., Grol, R.P., Zaat, J.O., Spies, T.H., van der Bij, A.K., Mokkink, H.G., 2003. Characteristics of effective clinical guidelines for general practice. Br. J. Gen. Pract. 53, 1519.

Cabana, M.D., Rand, C.S., Powe, N.R., Wu, A.W., Wilson, M.H., Abboud, P.A., Rubin, H.R., 1999. Why Don’t Physicians Follow Clinical Practice Guidelines? A Framework for Improvement. JAMA 282, 1458-1465. 
Canadian Task Force on Preventive Health Care, 2003. New Grades for Recommendations from the Canadian Task Force on Preventive Health Care. CMAJ 169, 207-208.

Canadian Task Force on Preventive Health Care (CTFPHC), 2011. Procedure Manual, viewed 12 November 2012, http://www.ualberta.ca/ mtonelli/manual.pdf

Canadian Task Force on Preventive Health Care (CTFPHC), 2012. Homepage, viewed 12 November 2012, http://www.canadiantaskforce.ca

Carlsen, B., Bringedal, B., 2011. Attitudes to clinical guidelines - do GPs differ from other medical doctors? BMJ Qual. Saf. 20, 158-162.

French National Authority for Health, 2009. Haute Autorité de Santé: Annual Report 2009 Summary, viewed 12 November 2012, http://www.has-sante.fr/portail/upload/docs/application/pdf/201010/annual-report -2009-summary.pdf

French National Authority for Health, 2010. Guide méthodologique: Elaboration de recommandations de bonne pratique, méthode « Recommandations pour la pratique clinique », viewed 12 November 2012, http://www.has-sante.fr/portail/upload/docs/application/pdf/201101/guide_methodologique_recommandations_pour_la_pratique_clinique.pdf

French National Authority, 2011. Recommandations de bonne pratique, viewed 12 November 2012, http://www.has-sante.fr/portail/jcms/c_5233/rechercheavancee?searchInFiles $=$ true $\&$ text $=\&$ mode $=$ advanced $\&$ searchedAllFields $=$ true $\&$ catName $=$ true $\&$ replaceFileDoc=false \&typesf $=$ generated.GuideMedecinALD $\&$ typesf $=$ generated. Recomman dationsProfessionnelles\&catMode $=$ and \&date

Grol, R., 2001. Successes and failures in the implementation of evidence-based guidelines for clinical practice. Med. Care 39, 46-54.

Harris, J.R., Cheadle, A., Hannon, P.A., Forehand, M., Lichiello, P., Mahoney, E., Snyder, S., Yarrow, J., 2012. A Framework for Disseminating Evidence-Based Health Promotion Practices; Prev. Chronic Dis. 9, 22, doi: http: 10.5888/pcd9.110081

Hayward, R.S., Steinberg, E.P., Ford, D.E., Roizen, M.F., Roach, K.W., 1991. Preventive care guidelines: 1991. American College of Physicians. Canadian Task Force on the Periodic Health Examination. United States Preventive Services Task Force. Ann. Intern. Med. 114, 758-83. 
Herland, K., Akselsen, J.P., Skjønsberg, O.H., Bjermer, L., 2005. How representative are clinical study patients with asthma or COPD for a larger "real life" population of patients with obstructive lung disease? Respir. Med. 99, 11-9.

Hulscher, M., Wensing, M., van der Weijden, T., Grol, R., 2006. Interventions to implement prevention in primary care. Cochrane Database Syst. Rev. doi: 10.1002/14651858.CD000362.pub2

Hutchings, A., Raine, R., 2006. A systematic review of factors affecting the judgments produced by formal consensus development methods in health care. J. Health Serv. Res. Policy 11, 172179.

Kanis, J.A., Torgerson, D., Cooper, C., 2000. Comparison of the European and USA practice guidelines for Osteoporosis. Trends Endocrinol. Metab. 11, 28-32.

Krist A.H., Woolf S.H., Rothemich S.F., Johnson R.E, Peele J.E., Cunningham T.D., Longo D.R., Bello G.A., Matzke G.R., 2012. Interactive preventive health record to enhance delivery of recommended care: a randomized trial. Ann. Fam. Med. 2012, 10, 312-319.

International Agency for Research on Cancer, 2013. IARC screening group, viewed 22 February 2013 http://screening.iarc.fr on.

National Cancer Institute, 2012. International Cancer Screening Network, viewed 22 February 2013, http://appliedresearch.cancer.gov/icsn

Leavell, H., Clark, E., 1965. Preventive medicine for the doctor in his community: an epidemiological approach, 7th edn, McGraw-Hill, New York.

Lugtenberg, M., Burgers, J.S., Besters, C.F., Han, D., Westert, G.P., 2011. Perceived barriers to guideline adherence: a survey among general practitioners. BMC Fam. Pract. 12, 98.

Mallery, L., Rockwood, K., 1992. Preventive Care for the Elderly: Uncovering the unmet needs of this population. Can. Fam. Physician 38, 2371-2379.

McAlister, F.A., van Diepen, S., Padwal, R.S., Johnson, J.A., Majumdar, S.R., 2007. How evidencebased are the recommendations in evidence-based guidelines? PLoS Med. 4, e250.

McMurray, J., Swedberg, K., 2006. Treatment of chronic heart failure: A comparison between the major guidelines. Eur. Heart. J. 27, 1773-1777.

Mavriplis, C., Thériault, G., 2006. The periodic health examination: a comparison of United States and Canadian recommendations. Can. Fam. Physician 52, 58-63. 
Milone, S.D., Milone, S.L., 2006. Evidence-based periodic health examination of adults. Memory aid for primary care physicians. Can. Fam. Physician 52, 40-47.

National Institute for Health and Clinical Excellence (NICE), 2012. Published public health guidance, viewed 12 November 2012, http://www.nice.org.uk

Organisation for Economic Co-operation and Development, 2011. Health at a Glance 2011: OECD indicators, doi: 10.1787/health_glance-2011-en

Public Health Agency of Canada, 1994. The Canadian Guide to Clinical Preventive Health Care, viewed 12 November 12, http://www.phac-aspc.gc.ca/publicat/clinic-clinique/index-eng.php

Qaseem, A., Forland, F., Macbeth, F., Ollenschläger, G., Phillips, S., van der Wees, P., Board of Trustees of the Guidelines International Network, 2012. Guidelines International Network: toward international standards for clinical practice guidelines. Ann. Intern. Med. 156, 525531.

Royal Australian College of General Practitioners, 2009. Putting prevention into practice: guidelines for the implementation of prevention in the general practice setting, 2nd edN, viewed 12 November 2012, http://www.racgp.org.au/Content/Navigation Menu/ClinicalResources/RACGPGuidelines/TheRedBook/redbook_7th_editionMay_2009.pdf

Sakji, S., Thirion, B., Dahamna, B., Darmoni, S.J., 2009. Searching French institutional health information sources: catalogue and index of French-language medical sites (CISMeF). Presse Med. 38, 1443-1450.

Stange, K.C., Flocke, S.A., Goodwin, M.A., Kelly, R.B., Zyzanski, S.J., 2000. Direct observation of rates of preventive service delivery in community family practice. Prev. Med. 31, 167-176.

Starfield, B., Shi, L., Macinko, J., 2005. Contributions of primary care to health systems and health. Milbank Quaterly 83, 457-502.

U.S. Preventive Services Task Force (USPSTF), 2008a. Grade definitions, viewed 12 November 2012, http://www.uspreventiveservicestaskforce.org/uspstf/grades.htm

U.S. Preventive Services Task Force (USPSTF), 2008b. Procedure Manual, viewed 12 November 2012, http://www.uspreventiveservicestaskforce.org/uspstf08/methods/procmanual.htm

U.S. Preventive Services Task Force (USPSTF), 2010a. Guide to Clinical Preventive Services, 20102011: Recommendations of the U.S. Preventive Services Task Force, Agency for Healthcare 
Research and Quality, Rockville, no. 10-05145, viewed 12 November 2012, http://www.ahrq.gov/clinic/pocketgd1011

U.S. Preventive Services Task Force (USPSTF), 2010 b. Counseling for Household and Recreational Injuries, viewed 12 November 2012, http://www.uspreventiveservicestaskforce.org/uspstf/uspshrin.htm

U.S. Preventive Services Task Force, 2010c. Screening for Hearing Loss in Older Adults, viewed 12 November 2012, http://www.uspreventiveservicestaskforce.org/uspstf/uspshear.htm

World Health Organization, 2011. World Health Statistics 2011, viewed 12 November 2012, http://www.who.int/whosis/whostat/2011/en/index.html

Yarnall, K.S., Pollak, K.I., Østbye, T., Krause, K.M., Michener, J.L., 2003. Primary care: is there enough time for prevention? Am. J. Public Health 93, 635-641. 


\section{TABLES AND FIGURES}

TABLE 1: DEFINITION OF AN EQUIVALENT GRADE OF RECOMMENDATION FOR THIS STUDY, TAKING INTO ACCOUNT THE SUCCESSIVE GRADE DEFINITIONS FROM THE CANADIAN, FRENCH AND US GRADING SYSTEMS UP TO NOVEMBER $3^{\text {RD }}, 2011$.

\begin{tabular}{|c|c|c|c|c|c|}
\hline $\begin{array}{l}\text { Eq. } \\
\text { grade }\end{array}$ & $\begin{array}{l}\text { CTFPHC } \\
\text { ( } \geq \text { August 2003) }\end{array}$ & $\begin{array}{l}\text { CTFPHC } \\
(<\text { August 2003) }\end{array}$ & $\begin{array}{l}\text { French National } \\
\text { Authority For Health }\end{array}$ & $\begin{array}{l}\text { USPSTF } \\
\text { ( } \geq \text { May 2007) }\end{array}$ & $\begin{array}{l}\text { USPSTF } \\
(<\text { May 2007) }\end{array}$ \\
\hline+2 & $\begin{array}{l}\text { A-Good evidence to } \\
\text { recommend }\end{array}$ & $\begin{array}{l}\text { A-Good evidence to } \\
\text { recommend }\end{array}$ & $\begin{array}{l}\text { A - Scientific evidence } \\
\text { established }\end{array}$ & $\begin{array}{l}\text { A - Recommended, with } \\
\text { high certainty to } \\
\text { recommend }\end{array}$ & $\begin{array}{l}\text { A - Strongly } \\
\text { Recommended }\end{array}$ \\
\hline \multirow[t]{2}{*}{+1} & $\begin{array}{l}\mathrm{B} \text { - Fair evidence to } \\
\text { recommend }\end{array}$ & $\begin{array}{l}\mathrm{B} \text { - Fair evidence to } \\
\text { recommend }\end{array}$ & $\begin{array}{l}\mathrm{B}-\text { Scientific } \\
\text { presumption } \\
\mathrm{C} \text { - Low level of evidence }\end{array}$ & $\begin{array}{l}\mathrm{B}-\text { Recommended, with } \\
\text { moderate certainty }\end{array}$ & B - Recommended \\
\hline & Do not exist & Do not exist & Professional consensus & Do not exist & Do not exist \\
\hline \multirow[t]{2}{*}{$\mathbf{0}$} & $\begin{array}{l}\mathrm{C} \text { - The existing evidence } \\
\text { is conflicting }\end{array}$ & Do not exist & No consensus & Do not exist & $\begin{array}{l}\mathrm{C}-\text { No recommendation } \\
\text { for or against this service }\end{array}$ \\
\hline & I - Insufficient evidence & $\mathrm{C}$ - Insufficient evidence & Do not exist & $\begin{array}{l}\text { I - Current evidence is } \\
\text { insufficient }\end{array}$ & I - Insufficient evidence \\
\hline \multirow[t]{2}{*}{-1} & Do not exist & Do not exist & $\begin{array}{l}\text { Professional consensus (to } \\
\text { exclude)* }\end{array}$ & Do not exist & Do not exist \\
\hline & $\begin{array}{l}\mathrm{D} \text { - Fair evidence to } \\
\text { recommend against }\end{array}$ & $\begin{array}{l}\mathrm{D} \text { - Fair evidence to } \\
\text { recommend against }\end{array}$ & $\begin{array}{l}\mathrm{C} \text { - Low level of evidence } \\
\text { (to exclude)* }\end{array}$ & $\begin{array}{l}\mathrm{C}-\text { Recommends against } \\
\text { (moderate certainty) }\end{array}$ & Do not exist \\
\hline
\end{tabular}




\begin{tabular}{|c|c|c|c|c|c|}
\hline $\begin{array}{l}\text { Eq. } \\
\text { grade }\end{array}$ & $\begin{array}{l}\text { CTFPHC } \\
\text { ( } \geq \text { August 2003) }\end{array}$ & $\begin{array}{l}\text { CTFPHC } \\
\text { (< August 2003) }\end{array}$ & $\begin{array}{l}\text { French National } \\
\text { Authority For Health }\end{array}$ & $\begin{array}{l}\text { USPSTF } \\
\text { ( } \geq \text { May 2007) }\end{array}$ & $\begin{array}{l}\text { USPSTF } \\
(<\text { May 2007) }\end{array}$ \\
\hline & & & $\begin{array}{l}\text { B - Scientific } \\
\text { presumption (to exclude)* }\end{array}$ & & \\
\hline-2 & $\begin{array}{l}\text { E-Good evidence to } \\
\text { recommend against }\end{array}$ & $\begin{array}{l}\text { E-Good evidence to } \\
\text { recommend against }\end{array}$ & $\begin{array}{l}\text { A - Scientific evidence } \\
\text { established (to exclude)* }\end{array}$ & $\begin{array}{l}\text { D - Recommendation } \\
\text { against, with high } \\
\text { certainty }\end{array}$ & D - Not recommended \\
\hline
\end{tabular}

Eq. grade: Equivalent grade of recommendation. CTFPHC: Canadian Task Force on Preventive Health Care; USPSTF: United States Preventive Services Task Force. *Considering the absence of a French grade that specifically recommends excluding a given preventive service, negatively worded recommendations were reviewed as such (e.g. "There is no need to perform routine screening for hypothyroidism (A grade)" was graded as "There is good evidence to recommend against routine screening for hypothyroidism (E grade)", which is equivalent to "-2" according to our system of equivalence). 
Figure 1: FloW ChaRT OF SELECTION AND SPLITTING PROCESS OF THE CANADIAN, FRENCH AND US RECOMMENDATIONS ON PREVENTION IN ADULTS PUBLISHED UP TO NOVEMBER $3^{\mathrm{RD}}$, 2011.

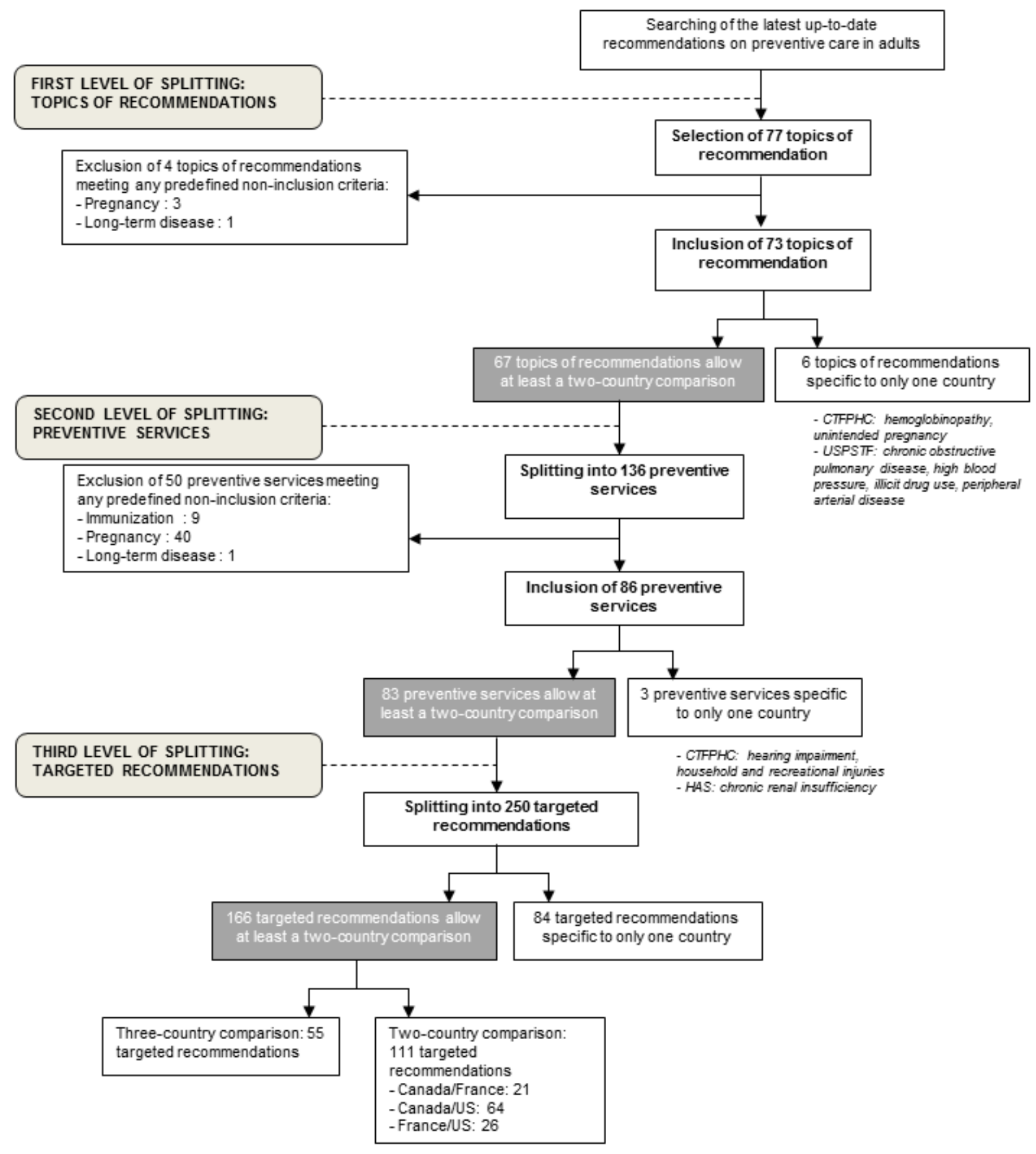

CTFPHC: Canadian Task Force on Preventive Heal th Care; HAS: the current acronym for the French National Authority for Health. USPSTF : United States Preventive Services Task Force. 
TABLE 2: DESCRIPTION OF THE CHARACTERISTICS OF THE 250 TARGETED

RECOMMENDATIONS ON PREVENTION IN ADULTS ACCORDING TO THEIR CLINICAL

CATEGORY, THE SEQUENCE OF STEPS OF THE MEDICAL CONSULTATION, THE TARGET

POPULATION, AND THE GRADING INFORMATION, BASED ON THE CANADIAN, FRENCH ET US RECOMMENDATIONS INCLUDED UP TO NOVEMBER $3^{\text {RD }}, 2011$ *

\begin{tabular}{|c|c|c|c|}
\hline & \multicolumn{3}{|c|}{ Number of targeted recommendations } \\
\hline & $\begin{array}{c}\text { CANADA } \\
(\mathbf{n}=\mathbf{1 7 5})\end{array}$ & $\begin{array}{c}\text { FRANCE } \\
(n=124)\end{array}$ & $\begin{array}{c}\text { US } \\
(\mathbf{n}=\mathbf{1 7 2})\end{array}$ \\
\hline \multicolumn{4}{|l|}{ Clinical categories } \\
\hline Cancers & $60(34 \%)$ & $40(32 \%)$ & $71(41 \%)$ \\
\hline Cardio vascular diseases & $24(14 \%)$ & $27(22 \%)$ & $30(17 \%)$ \\
\hline Infectious diseases & $22(13 \%)$ & $11(9 \%)$ & $30(17 \%)$ \\
\hline Injury / Mental health / & $31(18 \%)$ & $18(15 \%)$ & $19(11 \%)$ \\
\hline \multicolumn{4}{|l|}{ Musculoskeletal disorders } \\
\hline $\begin{array}{l}\text { Metabolic, nutritional, and } \\
\text { endocrine conditions }\end{array}$ & $26(15 \%)$ & $24(19 \%)$ & $19(11 \%)$ \\
\hline Miscellaneous & $12(7 \%)$ & $4(3 \%)$ & $3(2 \%)$ \\
\hline \multicolumn{4}{|c|}{ Sequence of steps of the medical consultation } \\
\hline $\begin{array}{l}\text { History-taking, physical } \\
\text { examination }\end{array}$ & $19(11 \%)$ & $17(14 \%)$ & $21(12 \%)$ \\
\hline Counseling & $56(32 \%)$ & $32(26 \%)$ & $30(17 \%)$ \\
\hline Techniques and procedures & $86(49 \%)$ & $64(52 \%)$ & $107(62 \%)$ \\
\hline Intervention & $14(8 \%)$ & $11(9 \%)$ & $14(8 \%)$ \\
\hline \multicolumn{4}{|l|}{ Target population } \\
\hline \multicolumn{4}{|l|}{ Gender } \\
\hline Only for men & $26(15 \%)$ & $27(22 \%)$ & $30(17 \%)$ \\
\hline Only for women & $48(27 \%)$ & $48(39 \%)$ & $56(33 \%)$ \\
\hline For both genders & $101(58 \%)$ & $49(40 \%)$ & $86(50 \%)$ \\
\hline \multicolumn{4}{|l|}{ Age } \\
\hline Individuals over 50 & $48(27 \%)$ & $30(24 \%)$ & $45(26 \%)$ \\
\hline Individuals under 50 & $17(10 \%)$ & $19(15 \%)$ & $21(12 \%)$ \\
\hline Different age limits & $110(63 \%)$ & $75(60 \%)$ & $106(62 \%)$ \\
\hline
\end{tabular}




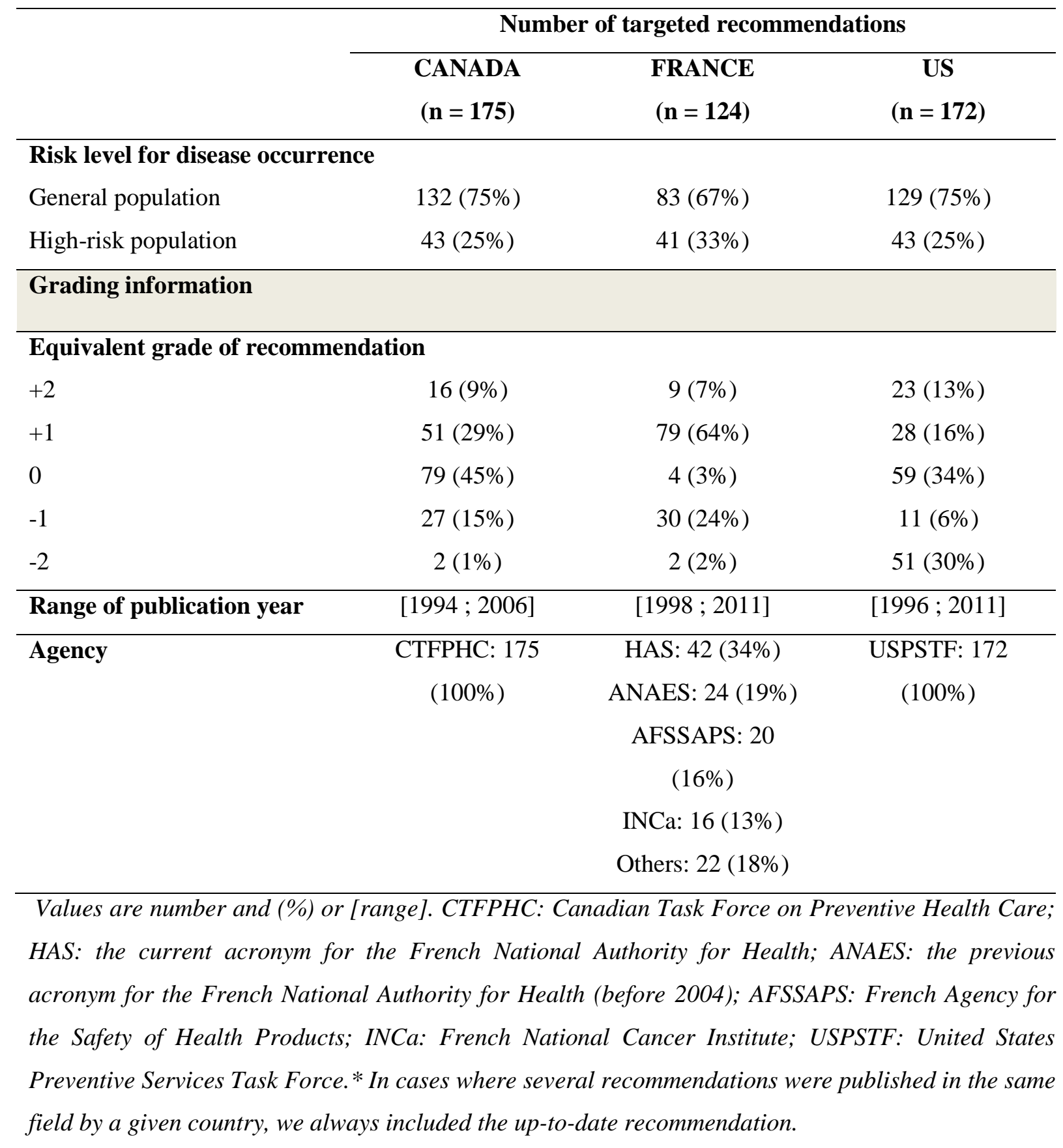




\section{TABLE 3: LEVEL OF AGREemEnT BeTWEen THE CANADIAN, FRENCH AND US TARGETED RECOMMENDATIONS INCLUDED UP TO NOVEMBER $3^{\text {RD }}, 2011$.}

\begin{tabular}{|c|c|c|c|c|c|c|}
\hline & \multicolumn{6}{|c|}{ Number of targeted recommendations } \\
\hline & \multicolumn{5}{|c|}{ Comparison between at least two countries } & \multirow{2}{*}{$\begin{array}{c}\text { No possible } \\
\text { comparison } \\
\text { (n) }\end{array}$} \\
\hline & $\mathbf{N}$ & $\begin{array}{c}\text { Strong } \\
\text { agreement }\end{array}$ & $\begin{array}{c}\text { Intermediate } \\
\text { agreement }\end{array}$ & $\begin{array}{c}\text { Major } \\
\text { disagreement }\end{array}$ & $\begin{array}{c}\text { Fisher's } \\
\text { exact test } \\
(p)\end{array}$ & \\
\hline \multicolumn{7}{|c|}{ Overall level of agreement } \\
\hline & 166 & $43(26 \%)$ & $82(49 \%)$ & $41(25 \%)$ & & 84 \\
\hline Clinical category & & & & & $\mathbf{0 . 1 0}$ & \\
\hline Cancers & 64 & $13(20 \%)$ & $31(48 \%)$ & $20(31 \%)$ & & 25 \\
\hline $\begin{array}{r}\text { Cardio vascular } \\
\text { diseases }\end{array}$ & 30 & $7(23 \%)$ & $13(43 \%)$ & $10(33 \%)$ & & 15 \\
\hline $\begin{array}{r}\text { Infectious } \\
\text { diseases }\end{array}$ & 23 & $6(26 \%)$ & $14(61 \%)$ & $3(13 \%)$ & & 9 \\
\hline Injury / Mental & & & & & & \\
\hline $\begin{array}{r}\text { health / Musc. } \\
\text { dis. }\end{array}$ & 23 & $12(52 \%)$ & $9(39 \%)$ & $2(9 \%)$ & & 15 \\
\hline $\begin{array}{l}\text { Metab., } \\
\text { nutritional, and } \\
\text { endocrine cond. }\end{array}$ & 21 & $4(19 \%)$ & $12(57 \%)$ & $5(24 \%)$ & & 13 \\
\hline Miscellaneous & 5 & $1(20 \%)$ & $3(60 \%)$ & $1(20 \%)$ & & 17 \\
\hline \multicolumn{4}{|c|}{ Sequence of steps of the medical consultation } & & 0.01 & \\
\hline $\begin{array}{r}\text { History-taking } \\
\text { and physical } \\
\text { examination }\end{array}$ & 19 & $10(53 \%)$ & $6(32 \%)$ & $3(16 \%)$ & & 14 \\
\hline Counseling & 37 & $12(32 \%)$ & $23(62 \%)$ & $2(5 \%)$ & & 29 \\
\hline $\begin{array}{r}\text { Techniques and } \\
\text { procedures }\end{array}$ & 98 & $20(20 \%)$ & $47(48 \%)$ & $31(32 \%)$ & & 34 \\
\hline Intervention & 12 & $1(8 \%)$ & $6(50 \%)$ & $5(42 \%)$ & & 7 \\
\hline \multicolumn{4}{|c|}{ Gender of the target population } & & 0.04 & \\
\hline Only for men & 30 & $5(17 \%)$ & $18(60 \%)$ & $7(23 \%)$ & & 10 \\
\hline Only for women & 52 & $9(17 \%)$ & $26(50 \%)$ & $17(33 \%)$ & & 21 \\
\hline
\end{tabular}




\begin{tabular}{|c|c|c|c|c|c|c|}
\hline & \multicolumn{6}{|c|}{ Number of targeted recommendations } \\
\hline & \multicolumn{5}{|c|}{ Comparison between at least two countries } & \multirow{2}{*}{$\begin{array}{c}\text { No possible } \\
\text { comparison } \\
\text { (n) }\end{array}$} \\
\hline & $\mathbf{N}$ & $\begin{array}{c}\text { Strong } \\
\text { agreement }\end{array}$ & $\begin{array}{c}\text { Intermediate } \\
\text { agreement }\end{array}$ & $\begin{array}{c}\text { Major } \\
\text { disagreement }\end{array}$ & $\begin{array}{c}\text { Fisher's } \\
\text { exact test } \\
(p)\end{array}$ & \\
\hline For both gender & 84 & $29(35 \%)$ & $38(45 \%)$ & $17(20 \%)$ & & 53 \\
\hline \multicolumn{4}{|c|}{ Age of the target population } & \multicolumn{3}{|c|}{0.08} \\
\hline Individuals over & & $7(15 \%)$ & $22(46 \%)$ & $19(40 \%)$ & & 11 \\
\hline 50 & 48 & & & & & \\
\hline Individuals under & 21 & $5(24 \%)$ & $11(52 \%)$ & $5(24 \%)$ & & 5 \\
\hline \multicolumn{7}{|l|}{50} \\
\hline Different age & 97 & $31(32 \%)$ & $49(51 \%)$ & $17(18 \%)$ & & 68 \\
\hline
\end{tabular}

Risk level for disease occurrence

0.009

\begin{tabular}{rlcccc}
\hline $\begin{array}{r}\text { General } \\
\text { population }\end{array}$ & 120 & $24(20 \%)$ & $62(52 \%)$ & $34(28 \%)$ & 66 \\
$\begin{array}{r}\text { High-risk } \\
\text { population }\end{array}$ & 46 & $19(41 \%)$ & $20(43 \%)$ & $7(15 \%)$ & 18
\end{tabular}

Maximum time range between recommendations' publication

$\mathbf{0 . 2 4}$

\begin{tabular}{rrrrrr}
\hline Less than 5 years & 43 & $16(37 \%)$ & $18(42 \%)$ & $9(21 \%)$ & \\
5 to 9 years & 41 & $8(20 \%)$ & $19(46 \%)$ & $14(34 \%)$ & \\
10 to 14 years & 52 & $11(21 \%)$ & $29(56 \%)$ & $12(23 \%)$ & \\
15 years or more & 30 & $8(27 \%)$ & $16(53 \%)$ & $6(20 \%)$ & \\
\hline $\begin{array}{r}\text { Proposal for clinical practice } \\
\text { To be }\end{array}$ & 78 & $25(32 \%)$ & $45(58 \%)$ & $8(10 \%)$ & \\
\hline $\begin{array}{r}\text { implemented } \\
\text { Indeterminate }\end{array}$ & 34 & $16(47 \%)$ & $6(18 \%)$ & $12(35 \%)$ & \\
about
\end{tabular}




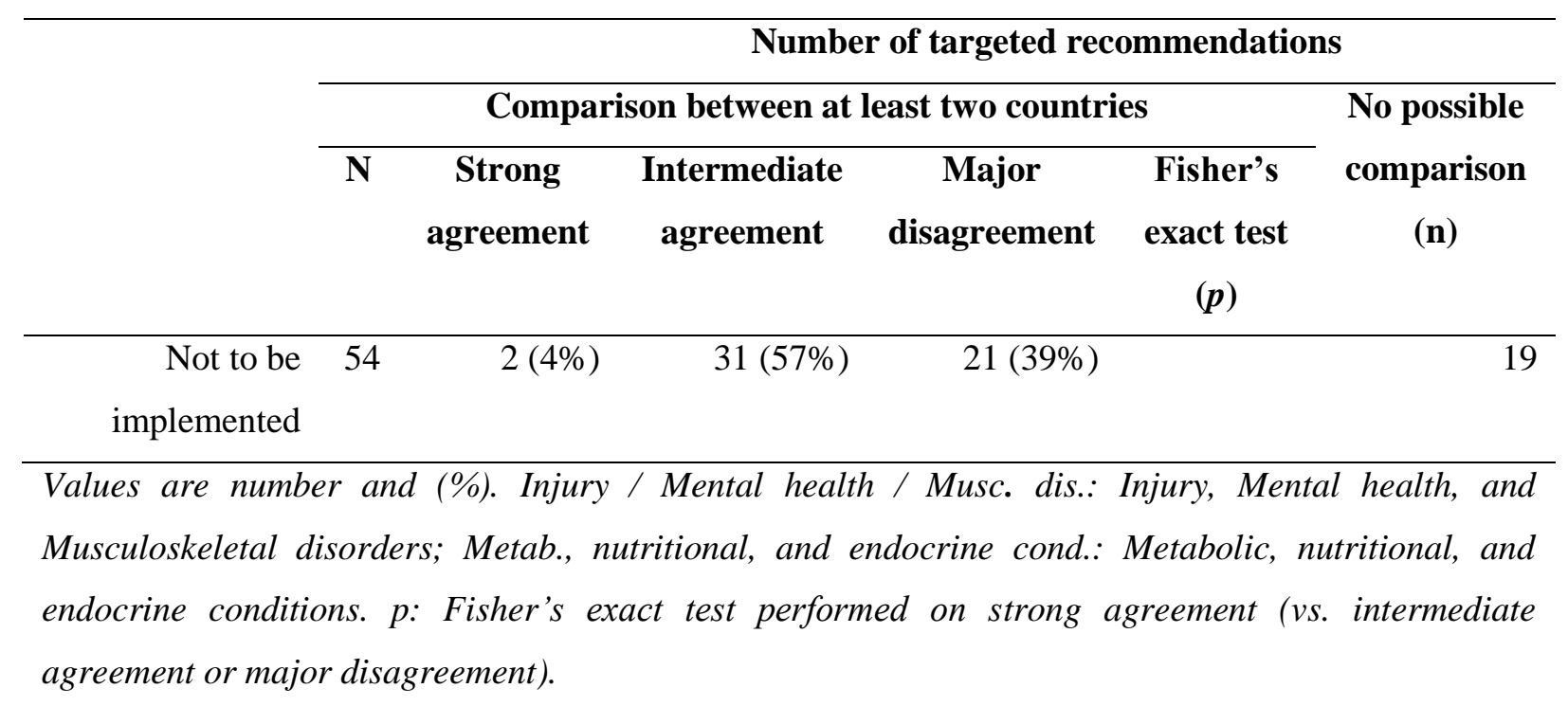


TABLE 4: TARGETED RECOMMENDATIONS WITH STRONG AGREEMENT BETWEEN CANADA, France AND THE USA, RESUlting IN A DEFINITE Proposal For Clinical PRACTICE (To BE IMPLEMENTED OR NOT TO BE IMPLEMENTED) UP TO NOVEMBER $3^{\text {RD }}, 2011$.

Target Population

\section{Preventive service}

\section{TO BE IMPLEMENTED IN CLINICAL PRACTICE}

\begin{tabular}{|c|c|c|c|}
\hline $\begin{array}{l}\text { BREAST AND } \\
\text { OVARIAN } \\
\text { CANCER* }\end{array}$ & $\begin{array}{l}\text { Women } \\
\text { High-risk population }\end{array}$ & $\begin{array}{l}\text { Referral for genetic counseling and } \\
\text { evaluation for BRCA testing for women } \\
\text { whose family history is associated with an } \\
\text { increased risk }\end{array}$ & $F R, U S$ \\
\hline OSTEOPOROSIS & $\begin{array}{l}\text { Women } \\
\text { General population }\end{array}$ & $\begin{array}{l}\text { Using history of previous fracture to } \\
\text { predict osteoporotic fractures }\end{array}$ & $C A, F R, U S$ \\
\hline $\begin{array}{l}\text { REDUCE } \\
\text { ALCOHOL } \\
\text { MISUSE }\end{array}$ & $\begin{array}{l}\text { Men or Women } \\
\text { General population }\end{array}$ & Case finding of problem drinking & $C A, F R, U S$ \\
\hline RUBELLA & $\begin{array}{l}\text { Women }<49 \\
\text { General population }\end{array}$ & $\begin{array}{l}\text { History of vaccination or serology, for } \\
\text { women of childbearing age }\end{array}$ & $C A, U S$ \\
\hline COUNSELING & & & \\
\hline $\begin{array}{l}\text { CORONARY } \\
\text { HEART DISEASE }\end{array}$ & $\begin{array}{l}\text { Men, 30-69 } \\
\text { General population }\end{array}$ & $\begin{array}{l}\text { General dietary advice on fat and } \\
\text { cholesterol }\end{array}$ & $C A, F R$ \\
\hline HEALTHY DIET & $\begin{array}{l}\text { Men, } 30-59 \\
\text { High-risk population }\end{array}$ & $\begin{array}{l}\text { Intensive behavioral dietary counseling } \\
\text { for adult patients with hyperlipidemia and } \\
\text { other known risk factors for } \\
\text { cardiovascular disease }\end{array}$ & $C A, F R, U S$ \\
\hline $\begin{array}{l}\text { REDUCE } \\
\text { ALCOHOL } \\
\text { MISUSE }\end{array}$ & $\begin{array}{l}\text { Men or Women } \\
\text { General population }\end{array}$ & $\begin{array}{l}\text { Behavioral counseling interventions to } \\
\text { reduce alcohol misuse }\end{array}$ & $C A, F R, U S$ \\
\hline $\begin{array}{l}\text { SEXUALLY } \\
\text { TRANSMITTED } \\
\text { INFECTIONS }\end{array}$ & $\begin{array}{l}\text { Men or Women } \\
\text { High-risk population }\end{array}$ & $\begin{array}{l}\text { High-intensity behavioral counseling to } \\
\text { prevent sexually transmitted infections }\end{array}$ & $C A, U S$ \\
\hline $\begin{array}{l}\text { TOBACCO USE } \\
\text { AND TOBACCO- } \\
\text { CAUSED } \\
\text { DISEASE }\end{array}$ & $\begin{array}{l}\text { Men or Women } \\
\text { General population }\end{array}$ & $\begin{array}{l}\text { Refer smokers to validated cessation } \\
\text { program }\end{array}$ & $C A, F R, U S$ \\
\hline
\end{tabular}




\begin{tabular}{|c|c|c|c|}
\hline & Target Population & Preventive service & $\begin{array}{l}\text { Advising } \\
\text { countries }\end{array}$ \\
\hline & $\begin{array}{l}\text { Men or Women } \\
\text { General population }\end{array}$ & $\begin{array}{l}\text { Counseling smoking cessation or nicotine } \\
\text { replacement therapy for smokers }\end{array}$ & $C A, F R$ \\
\hline \multicolumn{4}{|c|}{ TECHNIQUES AND PROCEDURES } \\
\hline \multirow[t]{2}{*}{$\begin{array}{l}\text { COLORECTAL } \\
\text { CANCER }\end{array}$} & $\begin{array}{l}\text { Men or Women } \\
\text { High-risk population }\end{array}$ & $\begin{array}{l}\text { Genetic testing and flexible } \\
\text { sigmoidoscopy for kindred with Familial } \\
\text { Adenomatous Polyposis (FAP) }\end{array}$ & $C A, F R$ \\
\hline & $\begin{array}{l}\text { Men or Women } \\
\text { High-risk population }\end{array}$ & $\begin{array}{l}\text { Colonoscopy for kindred with Hereditary } \\
\text { Non Polyposis Colorectal Cancer } \\
\text { (HNPCC) }\end{array}$ & $C A, F R$ \\
\hline DEPRESSION & $\begin{array}{l}\text { Men or Women } \\
\text { General population }\end{array}$ & $\begin{array}{l}\text { Screening in primary care settings when } \\
\text { staff-assisted depression care supports are } \\
\text { in place to ensure accurate diagnosis, } \\
\text { effective follow-up and treatment }\end{array}$ & $C A, U S$ \\
\hline $\begin{array}{l}\text { LIPID } \\
\text { DISORDERS }\end{array}$ & $\begin{array}{l}\text { Men, 20-29 } \\
\text { High-risk population }\end{array}$ & $\begin{array}{l}\text { Screening if they are at increased risk for } \\
\text { coronary heart disease }\end{array}$ & $F R, U S$ \\
\hline & $\begin{array}{l}\text { Women, 20-44 } \\
\text { High-risk population }\end{array}$ & $\begin{array}{l}\text { Screening if they are at increased risk for } \\
\text { coronary heart disease }\end{array}$ & $F R, U S$ \\
\hline OSTEOPOROSIS* & $\begin{array}{l}\text { Women } \\
\text { High-risk population }\end{array}$ & $\begin{array}{l}\text { Screening using Bone Mineral Density to } \\
\text { predict fractures }\end{array}$ & $C A, F R, U S$ \\
\hline RUBELLA & $\begin{array}{l}\text { Women }<49 \\
\text { General population }\end{array}$ & $\begin{array}{l}\text { Screening by serology and vaccinate } \\
\text { against rubella for non-pregnant women } \\
\text { of childbearing age }\end{array}$ & $C A, F R, U S$ \\
\hline \multirow[t]{2}{*}{$\begin{array}{l}\text { TYPE } 2 \\
\text { DiABETES } \\
\text { MELLITUS }\end{array}$} & $\begin{array}{l}\text { Men or Women } \\
\text { High-risk population }\end{array}$ & Screening adults with hypertension & $C A, F R, U S$ \\
\hline & $\begin{array}{l}\text { Men or Women }>45 \\
\text { High-risk population }\end{array}$ & Screening adults with hyperlipidemia & $C A, F R$ \\
\hline \multicolumn{4}{|c|}{ NOT TO BE IMPLEMENTED IN CLINICAL PRACTICE } \\
\hline \multicolumn{4}{|c|}{ HISTORY-TAKING AND PHYSICAL EXAMINATION } \\
\hline $\begin{array}{l}\text { ASYMPTOMATIC } \\
\text { BACTERIURIA }\end{array}$ & $\begin{array}{l}\text { Men or Women }>65 \\
\text { High-risk population }\end{array}$ & $\begin{array}{l}\text { Urine dipstick or culture in elderly and } \\
\text { specific subgroups }\end{array}$ & US, CA \\
\hline $\begin{array}{l}\text { CHLAMYDIA } \\
\text { INFECTION }\end{array}$ & $\begin{array}{l}\text { Women }>25 \\
\text { General population }\end{array}$ & $\begin{array}{l}\text { Screening for Chlamydia infection } \\
\text { (smear, culture or analysis) }\end{array}$ & US, CA \\
\hline
\end{tabular}


CA: Canada; FR: France; US: United States. * The 25 targeted recommendations with strong agreement resulting in a "To be implemented" proposal for practice were merged into 20 recommendations so as to make the understanding of the results in this table easier. 